\title{
Photoadaptation and primary production study in tidally mixed coastal waters using a Lagrangian model
}

\author{
F. Lizon*, L. Seuront, Y. Lagadeuc \\ Station Marine de Wimereux, Université des Sciences et Technologies de Lille, CNRS EP 1750, BP 80, \\ F-62930 Wimereux, France
}

\begin{abstract}
In theoretical and field primary production studies, much interest is currently focused on the influence of aperiodic vertical mixing generated at the surface by wind speed and/or heat flux. In the present work, a Lagrangian random walk model was used to study the interactions between periodic vertical tidal mixing and both photoadaptation and primary production of phytoplankton, in typical shallow coastal waters, such as the eastern English Channel. The model considers a depthdependent diffusion coefficient fluctuating according to the high-low tidal cycles and neap-spring tidal cycles, water columns of different euphotic zone and mixed layer depths, and photoresponse time constants of natural phytoplankton populations collected in the eastern English Channel. Cells were allowed to light-shade adapt, according to the vertical mixing time scales, by aitering therr photosynthetic properties in response to variations in light. The simulation results indicate first that vertical tidal mixing could control photoadaptation processes at the scale of the high-low tidal cycles at spring tide, and at the scale of neap-spring tidal cycles in shallow coastal systems. Secondly, it appears that the decreasing vertical mixing intensity between spring and neap tide conditions is responsible for a significant increase in daily primary production rates, despite the occurrence of photoinhibition at neap tide. Therefore, primary production in coastal seas would be a function not only of light and nutrient concentrations, but also of photoadaptation processes in relation with vertical tidal mixing. In another way, the Lagrangian model suggests that the theory according to which cells are adapted to the mean light intensity of a water column in a turbulent regime is valid only from a populational point of view. From the model used, it appears also that our present knowledge on photosynthetic dynamic modeling is unsuited to generating pronounced vertical gradients of photosynthetic parameters in all water columns.
\end{abstract}

KEY WORDS: Models - Phytoplankton - Photosynthetic parameters Photoadaptation kinetic - Primary production Vertical tidal mixing Coastal waters - Eastern English Channel

\section{INTRODUCTION}

In natural environments, phytoplankton cells experience light variations due to astronomical cycles, cloud cover, and also to vertical motion caused by turbulent mixing encountered in the water columns. Phytoplankton can respond to these light variations by photoadaptation processes (Harris 1980, Capblancq 1995).

Conceptual bases of phytoplankton photoadaptation in response to vertical mixing have been provided by studies by Marra (1978a, b), Falkowski (1980), Perry et al. (1981), Falkowski \& Wirick (1981), Falkowski

·E-mail: lizon@loalit.univ-littoral.fr
(1983) and Lewis et al. (1984a). These consist of an adaptation of cells to the vertical gradient of light when the time-scales of physiological processes are shorter than those of vertical mixing events. The photosynthetic characteristics of phytoplankton, such as the parameters of the photosynthesis versus irradiance curves, then display heterogeneities in the water column. In contrast, if vertical mixing takes place on lower time-scales than those of photoadaptation, photosynthetic properties of phytoplankton are expected to be more uniformly distributed with depth. In agreement with these theoretical considerations, it has recently been shown that photoadaptation of phytoplankton can take place at neap tide, in a shallow 
coastal system like the eastern English Channel, influenced mostly by the tide (Lizon et al. 1995). In this area, the occurrence of photoadaptation processes was not obvious because the tidal range is one of the highest in the world (ranging from 3 to $9 \mathrm{~m}$ ), and the physical structure of the waters, chlorophyll a and nutrient profiles are more generally homogeneous (Lizon et al. 1995). Furthermore, photoadaptation processes occurring in the eastern English Channel have noticeable ecological implications. If they are not considered at neap tide, substantial bias (on the order of $40 \%$ ) can result in the daily primary production rate computations (Lizon et al. 1995)

Concurrently with field or experimental studies (Fortier \& Legendre 1979, Marra 1980, Lewis et al. 1984a, b, Mallin \& Paerl 1992, Kromkamp \& Limbeek 1993, Grobbelaar 1994), several models (Falkowski \& Wirick 1981. Woods \& Onken 1982, Lande \& Lewis 1989, Yamazaki \& Kamykowski 1991, Kamykowski et al. 1994, Weissing \& Huisman 1994, Woods \& Barkmann 1994) have been formulated in order to carry out thorough studies of interactions between vertical mixing and photoadaptation. The previously mentioned biological-physical interactions have been modelled in 2 fundamentally different ways. The first approach describes the average values of photosynthetic properties of a cell population at a given depth, according to vertical mixing intensity. This type of model can be labelled Eulerian or bulk property model. The second approach describes vertical displacements and physiological responses of individual phytoplankton cells in a water column. This kind of model, called Lagrangian model, is primarily of interest because it considers variability in the photosynthetic characteristic of phytoplankton that may exist among cells at the same depth. Such a variability, resulting from different indjvidual light exposure histories of cells in turbulent environments, matches with in situ measurements of the phytoplankton responses obtained, for example, by flow cytometry (Chisholm. et al. 1986, Li \& Wood 1988, OIson et al. 1991). Moreover, recent studies have shown-on the basis of innovative statistical techniques of analysis in oceanography - that phytoplankton biomass is heterogeneously distributed at microscale, though basically regarded as homogenised by turbulent fluid motions (Seuront et al. 1996a, b). Consequently, processes associated with primary production, or more generally processes encountered in marine environments, cannot be considered as average phenomena, but rather as a juxtaposition of many specific events such as individual photosynthetic responses. In this way, a Lagrangian approach along with the previous studies, leads to the characterization of each variability level rather than the description of an average process.
In the previous studies of photoadaptation in relation with turbulence, vertical mixing was always generated. by an upper mixed-layer model forced by wind speeds, and sometimes by heat flux. Hydrodynamical regimes were generally constant throughout the day. No theoretical or field study has been conducted on the influence of periodic variations of vertical mixing - which is generated at the bottom of shallow waters by tidal currents (Simpson et al. 1990, 1991) - on photosynthetic processes and daily primary production rates of phytoplankton. Some theoretical studies have considered periodic variations of vertical tidal mixing, but with regard to phytoplankton biomass only (Cloern 1991, Koseff et al. 1993, Baretta et al. 1995. Skogen et al. 1995). Other studies on the interactions between turbulence and photosynthesis have been conducted in situ, but in deep waters or in wind-driven turbulent waters (Fortier \& Legendre 1979, Demers \& Legendre 1981, Lewis et al. 1984b, Vézina et al. 1995, DelgadilloHinojosa et al. 1997). Furthermore, the conclusions of field studies about the effect of vertical mixing on primary production rates (increase or decrease) are often inconsistent (Marra 1978b, Mailin \& Paerl 1992, Delgadillo-Hinojosa et al. 1997). Thus, the aim of this paper is to conduct a theoretical study, using a Lagrangian model, on the interactions between vertical mixing (which changes according to high-low tidal cycles and neap-spring tidal cycles) and both photoadaptation processes and daily primary production rates in typical shallow coastal water columns. In this way, the variability of the environmental conditions involved in primary production control cannot hide a possible relationship between the previously mentioned physical and biological processes. Such a relationship is hypothesized here.

The model used in this study describes physiological properties of cells instead of cell concentrations. It takes into account both the photoresponse time constants of natural phytoplankton populations from the eastern English Channel and the tidal current speed measurements collected at the same place. For more clarity, non-mobile phytoplankton cells are considered in the present case. The sinking rate of cells and wind-driven turbulence are neglected. First, a detailed account of physical and biological aspects of our modelling is provided. Secondly, we focus on the relationships between vertical mixing related to tidal forcing and both photoadaptation and primary production processes.

\section{MATERIALS AND METHODS}

The physical model. In simple vertical transport models such as those used in some studies (Falkowski \& Wirick 1981, Yamazaki \& Kamykowski 1991, Koseff 
et al. 1993, Kamykowski et al. 1994, McGillicuddy 1995), the effect of turbulence on vertical mixing is typically parameterized by a depth-dependent diffusion coefficient $\left(K_{v}\right)$. Following Taylor (1954) and Koseff et al. (1993), eddy diffusivity is characterized by a turbulent velocity scale and a length scale which are respectively shear velocity $u^{*}$ and the depth of the water column in shallow systems. Since we consider only the tide as a source of turbulence in the present study, the vertical distribution of $K_{v}$ is parabolic (Koseff et al. 1993). Using the logarithmic law velocity profile, $K_{\text {. }}$ $\left(\mathrm{m}^{-2} \mathrm{~s}^{-1}\right.$ ) at depth $z$ and time $t$ is given by (Fisher et al. 1979, Koseff et al. 1993):

$$
K_{v}(z, t)=\left[\kappa \cdot u^{*}(t) \cdot H(t) \cdot\left(\frac{h(t)}{H(t)}\right) \cdot\left(1-\frac{h(t)}{H(t)}\right)\right]+K_{0}
$$

where $\kappa$ is the Von Karman constant (0.4), $K_{0}$ is a small value included so that the diffusivity is never equal to zero $\left(1 \times 10^{-5} \mathrm{~m}^{-2} \mathrm{~s}^{-1}\right.$, a value higher than the molecular diffusivity; cf. Koseff et al. 1993), and $h(t)$ is the distance between the depth of a particle, $Z(t)$ (see Eq. 7), and the depth of the water column, $H(t)$ (see Eq. 4). The shear velocity $u^{*}\left(\mathrm{~m} \mathrm{~s}^{-1}\right)$ is defined as (Dyer 1986):

$$
u^{*}(t)=\frac{\kappa \cdot u(t)}{\log \left(\frac{30 \cdot d}{k_{b}}\right)}
$$

where $k_{b}$ is the average diameter of the grains of sediment $(0.005 \mathrm{~m})$, and $u(t)$ is the current velocity calculated for a depth $d$, near the bottom of the water column. In order to treat current velocity variations according to both the semidiurnal (M2) and the neapspring (Mf) tidal cycles, current velocity $u(t)\left(\mathrm{m} \mathrm{s}^{-1}\right)$ was calculated by the standard following equation:

$$
u(t)=\left[\mathrm{A}+\mathrm{B} \cdot \sin \left(\frac{2 \pi t}{\mathrm{~T}_{\mathrm{Mi}}}\right)\right] \cdot \sin \left(\frac{2 \pi t}{\mathrm{~T}_{\mathrm{M} 2}}\right)
$$

where $A=0.95 \mathrm{~m} \mathrm{~s}^{-1}, \mathrm{~B}=0.43 \mathrm{~m} \mathrm{~s}^{-1}, \mathrm{~T}_{\mathrm{M} 2}=12.4 \mathrm{~h}$ and $\mathrm{T}_{\mathrm{M}}=14 \mathrm{~d}$. The 2 parameters $\mathrm{A}$ and $\mathrm{B}$ (the average and the range of current velocity variations at the scale of the neap-spring tidal cycles respectively) were calculated from in situ current velocity measurements made at a depth $d$ in different tidal conditions in the eastern English Channel (Lizon 1997). The depth of the water column, $H(t)(\mathrm{m})$, a time-dependent parameter, also ranges according to both the $\mathrm{M} 2$ and Mf tidal cycles:

$$
H(t)=\bar{H}+\zeta(t)
$$

where $\bar{H}(\mathrm{~m})$ is the average depth of a water column, and $\zeta(t)(\mathrm{m})$ is the range of the water elevation above the average depth of the water column. This last variable is defined from a model which depends on the semi-tidal range $a(t)(m)$ (G. Chapalain pers. comm.):

$$
\begin{aligned}
& \zeta(t)=a(t) \cdot \cos \left(\frac{2 \pi t}{\mathrm{~T}_{\mathrm{M} 2}}\right) \\
& a(t)=0.5\left[\mathrm{C}+\mathrm{D} \cdot \sin \left(\frac{2 \pi t}{\mathrm{~T}_{\mathrm{Mi}}}\right)\right]
\end{aligned}
$$

where $C=5.9 \mathrm{~m}$ and $\mathrm{D}=2 \mathrm{~m}$. These 2 parameters were also calculated from in situ water column depth variations in different tidal conditions in the eastern English Channel (Lizon 1997).

The location of a particle $Z(t)(\mathrm{m})$ is parameterized by a random walk model which considers the vertical eddy diffusion coefficient $K_{v}$ as (Pielou 1969, Falkowski \& Wirick 1981):

$$
Z(t)=Z(t-1) \pm\left[2 \Delta t \cdot K_{v}(Z, t)\right]^{1 / 2}
$$

where $\Delta t$ is the time interval (see below). A choice is made between the algebraical signs + and - with equal probability at each $\Delta t$. Following Falkowski \& Wirick (1981), the surface and bottom of the mixed layers are treated as reflective boundaries.

The diurnal light incident upon a cell at depth $z$ and time $t$ is given by:

$$
I(z, t)=I_{M} \sin \left(\frac{\pi t}{D L}\right) e^{\left|k_{\mathrm{d}} z(t)\right|}
$$

where $I_{M}$ is the light intensity on the water column surface at noon $\left(850 \mu \mathrm{E} \mathrm{m}^{-2} \mathrm{~s}^{2}\right)$, DL is the day length $(12 \mathrm{~h})$, and $k_{d}$ the extinction coefficient. These last parameters are considered constant for the study of daily primary production rates at the scale of the neapspring tidal cycles in a given water column.

The biological model. The biological model predicts the primary production rate $(P)$ by the empirical model of Platt et al. (1980), as a function of the light incident upon a cell $[I(z, t)$ notated $I$ in the following equation in order to simplify the expression], photosynthetic parameters and chlorophyll a concentration of a cell ( $\mathrm{B}=10 \mathrm{pg}$; Montagnes et al. 1994):

$$
P\left(I_{i} P_{\mathrm{m}}^{\mathrm{B}}, \alpha^{\mathrm{B}}, \beta^{\mathrm{B}}\right)=\mathrm{B} \cdot P_{\mathrm{m}}^{\mathrm{B}} \cdot\left(1-\mathrm{e}^{\left(-\alpha^{8} / / P_{\mathrm{m}}^{\mathrm{B}}\right)}\right) \cdot \mathrm{e}^{\left(-\beta^{B} / / P_{m}^{\mathrm{B}}\right)}
$$

where $P_{\mathrm{m}}^{\mathrm{B}}$ is the photosynthetic capacity [maximum of the photosynthesis-irradiance (PE) curve), $\alpha^{B}$ is the photosynthetic efficiency (slope of the PE curve at low light intensity), and $\beta^{B}$ a photoinhibition indice (slope of the PE curve at high irradiance).

According to the photoadaptation theory (Falkowski \& Owens 1980), phytoplankton cells are assumed to adapt each of their photosynthetic parameters $(\Gamma$ in abridged notation) after change in light towards fully adapted values $\Gamma_{i}^{*}$. Following Falkowski \& Owens (1980) and Falkowski \& Wirick (1981), $\Gamma_{1}^{*}$ can be parameterized by linear functions of the logarithm of the light intensity incident upon a cell, as:

$$
\Gamma_{i}^{*}=b_{\Gamma}+a_{\Gamma} \cdot \ln (I)
$$


Table 1. Initial values of photosynthet.c parameters $\left[p_{\mathrm{m}}^{\mathrm{B}}\right.$ is in $\mathrm{mgC} \mathrm{mg} \mathrm{chl} a^{-1} \mathrm{~h}^{-1}, \alpha^{B}$ and $\beta^{B}$ are in $\mathrm{mgC} \mathrm{mg} \mathrm{chl} a^{-1} \mathrm{~h}^{-1}(\mu \mathrm{E}$ $\left.\mathrm{m}^{-2} \mathrm{~s}^{-1}\right)^{-1} \mathrm{~J}$ and cell-specific constants used in the biological model for each photosynthetic parameters: $\gamma$-LI $\left(\mathrm{h}^{-1}\right)$ are kinetic constants obtained from low to high light shift experiments on natural population of phytoplankton; $\gamma-\mathrm{HI}\left(\mathrm{h}^{-1}\right)$, from the reciprocal light shifts; $\gamma$-inhib. $\left(\mathrm{h}^{-1}\right)$ is a kinetic constant determined when $P_{\mathrm{m}}^{\mathrm{B}}$ decreases after a shift under saturating light intensity; $a$ and $b$ are the cell-specific constants of Eq. (10), deduced from the different light shift experiments

\begin{tabular}{|llll|}
\hline & $P_{\mathrm{m}}^{\mathrm{B}}$ & $\alpha^{\mathrm{B}}$ & $\beta^{\mathrm{B}}$ \\
\hline Initial values & 2.5 & 0.05 & 0.005 \\
$\gamma$-LI & 0.462 & 0.278 & 0.131 \\
$\gamma$-HI & 0.262 & 0.477 & 0.425 \\
$\gamma$-inhib. & 0.656 & & \\
$a$ & 1.2 & -0.006 & -0.001 \\
$a$-inhib. & -0.4 & 0.07 & 0.007 \\
$b$ & 1.2 & 0.2 & \\
\hline
\end{tabular}

where $a_{\Gamma}$ and $b_{\Gamma}$ are cell-specific constants. The instantaneous values $\Gamma_{1}$ of the photosynthetic parameters can then be calculated according to first-order reaction kinetics (Cullen \& Lewis 1988):

$$
\frac{\mathrm{d} \Gamma_{i}}{\mathrm{~d} t}=\gamma_{\Gamma} \cdot\left(\Gamma_{i} \cdot-\Gamma_{1}\right)
$$

where $\gamma_{\Gamma}$ are first-order kinetic constants. The different cell-specific constants used $\left(a_{\Gamma}, b_{\Gamma}\right.$ and $\left.\gamma_{\Gamma}\right)$ are presented in Table 1 . They have been determined from light shift experiments (cf. Cullen \& Lewis 1988) of natural populations of phytoplankton collected in coastal waters of the eastern English Channel (Lizon 1997). Results are consistent with those of Cullen \& Lewis (1988). Significant different kinetic constants have been obtained from low to high light shifts and from the reciprocal light shifts (high to low irradiance). Therefore, kinetic constants of each parameter determined from low to high light shift experiments are used when cells are displaced to the surface of the water column. In the opposite case, kinetic constants of each parameter determined from high to low light shifts are considered.

The photoinhibition process is well known to induce $P_{m}^{\mathrm{B}}$ decreases near the sea surface under high light intensity (Harris 1980, Vincent et al. 1984, Neale \& Richardson 1987, Cullen \& Lewis 1988, Ferris \& Christian 1991). Such a process has been observed in our earlier works conducted in the eastern English Channel (Lizon et al. 1995) and during light shift experiments (Lizon 1997). Photoinhibition is therefore also taken into account in the present study. It is considered here as a photoadaptative process in agreement with Cullen \& Lewis (1988). In order to parameterize photoinhibition, $P_{m}^{B}$ values measured in the natural environment by Lizon et al. (1995) were fitted by Eqs. (10) \&

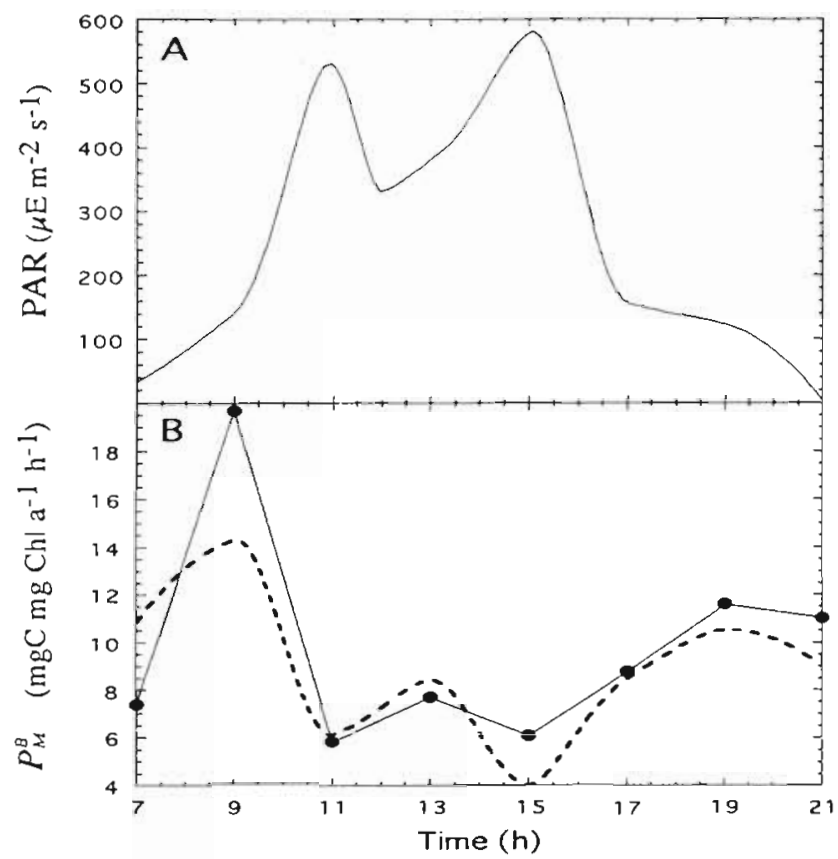

Fig. 1. (A) Irradiance and (B) $P_{\mathrm{m}}^{\mathrm{B}}$ icontinuous line) values (Lizon et al 1995) used to determine a specific value $a_{\Gamma}$ (cf. Eq. 10) for $P_{\mathrm{m}}^{\mathrm{B}}$, when light intensity induces photoinhibition processes. The best fit $\left(r^{2}=0.703\right)$ of the measured data (dashed line) was obtained with $a_{\Gamma}=-0.4$. PAR: photosynthetically active radiation

(11). For a light intensity higher than the photoinhibition threshold (450 $\mu \mathrm{E} \mathrm{m}^{-2} \mathrm{~s}^{-1}$ ) of photosynthesis, and with a particular kinetic constant (Table 1), we determined a specific value $a_{r}$ for $P_{m}^{B}$. It appears that the best fit $\left(\mathrm{r}^{2}=0.703\right)$ of the measured data is obtained under high light, with $a_{\Gamma}=-0.4$ (Fig. 1).

Implementation of the model. The software STELLA, which has been demonstrated to be an efficient tool to transfer a conceptual dynamic model into a practical computer model (Costanza 1987, Richmond et al. 1987, Wu \& Vankat 1991, Hannon \& Ruth 1994), was used in the present work.

In all Lagrangian models, vertical displacements of organisms are a function of the vertical eddy diffusivity coefficient $K_{v}$, but also of the time step $\Delta t$ (cf. Eq. 10). In the present case, $K_{v}$ is parameterized from in situ measurements of current speeds, and therefore displays fluctuations according to the low-high and neapspring tidal cycles (Fig. 2). The time step $\Delta t$ is determined following McGillicuddy (1995) and Barkmann \& Woods (1996), so that the mixed layer turnover times are consistent with measured values for mixing layers of similar extent. In this study, as for Barkmann \& Woods (1996), a time step of $6 \mathrm{~min}$ was used. The turnover times of 20 and $40 \mathrm{~m}$ depth water columns vertical extent of the largest eddies - are then on the order of $30 \mathrm{~min}$ and $1 \mathrm{~h} 30 \mathrm{~min}$ respectively at spring 


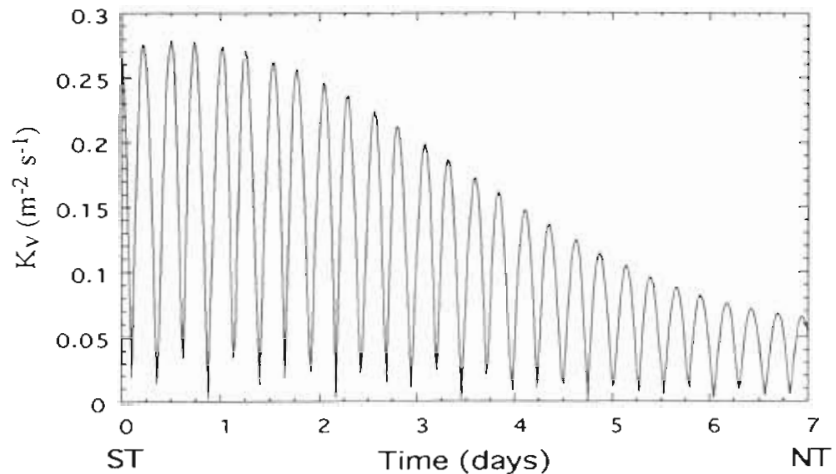

Fig. 2. Variations of the vertical eddy diffusivity coefficient $K_{v}$, at the scale of the semi-neap-spring tidal (NT-ST) cycle considered

tide, and on the order of $2 \mathrm{~h} 20 \mathrm{~min}$ and $7 \mathrm{~h} 30 \mathrm{~min}$ respectively at neap tide. Such turnover times are consistent with the values reported or used by many authors (Gargett et al. 1979, Denmann \& Gargett 1983, Shay \& Gregg 1986, McGillicuddy 1995, Barkmann \& Woods 1996) for high and low turbulence regimes in shallow mixing layers. However, in order to compare primary production rates between neap tide conditions and very weak turbulent regimes, additional simulations were made for very small $K_{v}$ values $\left(10^{-3}, 10^{-4}\right.$ and $10^{-5} \mathrm{~m}^{2} \mathrm{~s}^{-1}$ ), i.e. for turnover times up to $100 \mathrm{~h}$.

The biological model considers only photoadaptation processes at short time-scales. It takes no account of processes such as ontogenic adaptations (Kirk 1983), which can occur at long time-scales, i.e. at the scale of the neap-spring tidal cycles. The physiological properties of cells were the same at the beginning of each daylight period (12 h) (Table 1). Therefore, the model was run independently for each simulated day, i.e. for each vertical mixing condition.

At sunrise of each simulated day, 100 cells with the same photosynthetic characteristics were randomly placed within the mixed layer. At each time step $\Delta t$, new depths, new light intensities and new photosynthetic parameter values were calculated for each cell. Instantaneous va]ues of primary production were also calculated for each cell, and integrated over the daylight period with the 4th order Runge-Kutta method (Shampine \& Watts 1977). Since 100 cells is too small a number for study of phytoplankton responses from a statistical point of view, $3 \mathrm{sim}$ ulations with 100 cells were made for each tested vertical mixing condition. Thus, displayed daily primary production rates will square with the mean rates of the 3 simulations. Variation coefficients of the daily production rates will also be presented.

The interactions between vertical mixing intensity and daily primary production rates were studied at the scale of a semi-neap-spring tidal cycle ( $7 \mathrm{~d}$ ) for different typical water columns found in the eastern English
Table 2. Values of extinction coefficients $\left(k_{\mathrm{d}}\right)$, average depths $(\bar{H})$ of the coastal (CW), intermediate (IW) and offshore (OW) water columns considered in this study, and ratios between the euphotic zone and mixed layer depths $\left(Z_{\mathrm{e}} / Z_{\mathrm{m}}\right)$ of the 3 water columns

\begin{tabular}{|lccc|}
\hline & CW & IW & OW \\
\hline$k_{\alpha}\left(\mathrm{m}^{-1}\right)$ & 0.4 & 0.3 & 0.17 \\
$\bar{H}(\mathrm{~m})$ & 20 & 30 & 40 \\
$Z_{\mathrm{e}} / Z_{\mathrm{m}}$ & 0.49 & 0.53 & 0.68 \\
\hline
\end{tabular}

Channel, along an inshore-offshore transect. The extinction coefficients $\left(k_{\alpha}\right)$ and the average depths $(\bar{H})$ of the water columns were chosen from data collected in the coastal, offshore and intermediate waters of the eastern English Channel (Table 2; Lizon 1997). However, since the depths of the euphotic zones $\left(Z_{\mathrm{e}}\right)$ are all different from the depths of the mixed layers $\left(Z_{\mathrm{m}}\right)$ (i.e. depths of the water columns in the present case) in the 3 previous water masses (Table 2), additional simulations were made for waters where the $Z_{\mathrm{e}} / Z_{\mathrm{m}}$ ratio is equal to the unit.

\section{RESULTS AND DISCUSSĨON}

\section{Photoadaptation versus vertical mixing}

In Fig. 3, daily photosynthetic responses of some individual cells are presented for hydrodynamical regimes related to spring and neap tide. It appears that vertical heterogeneities of photosynthetic characteristics can take place both at neap and spring tide. At neap tide, such results are consistent with earlier studies conducted in the eastern English Channel (Lizon et a1. 1995, Lizon \& Lagadeuc 1998), whereas they are more surprising at spring tide. However, the results are relatively different between neap and spring tide conditions.

First, vertical gradients of photosynthetic responses match with the photoadaptation theory (Falkowski \& Owens 1980), but only under neap tide conditions. The decreases in $P_{\mathrm{m}}^{B}$ and the increases of $\alpha^{B}$ and $\beta^{B}$ with depth at neap tide indicate that phytoplankton cells adapt their photosynthetic properties to the vertical gradients of light for weak tidal forcing (Figs. $3 \& 4$ ). Pronounced photoinhibition processes also occur at neap tide, as shown by the weak values of $P_{\mathrm{m}}^{\mathrm{B}}$ in surface waters in the middle of the day (Fig. 3). On the contrary, at spring tide, vertical heterogeneities of photosynthetic parameters are inconsistent with a photoadaptation to the decreasing vertical gradient of light. Such heterogeneities may be due to the fact that cells tend to continuously adjust their photosynthetic 

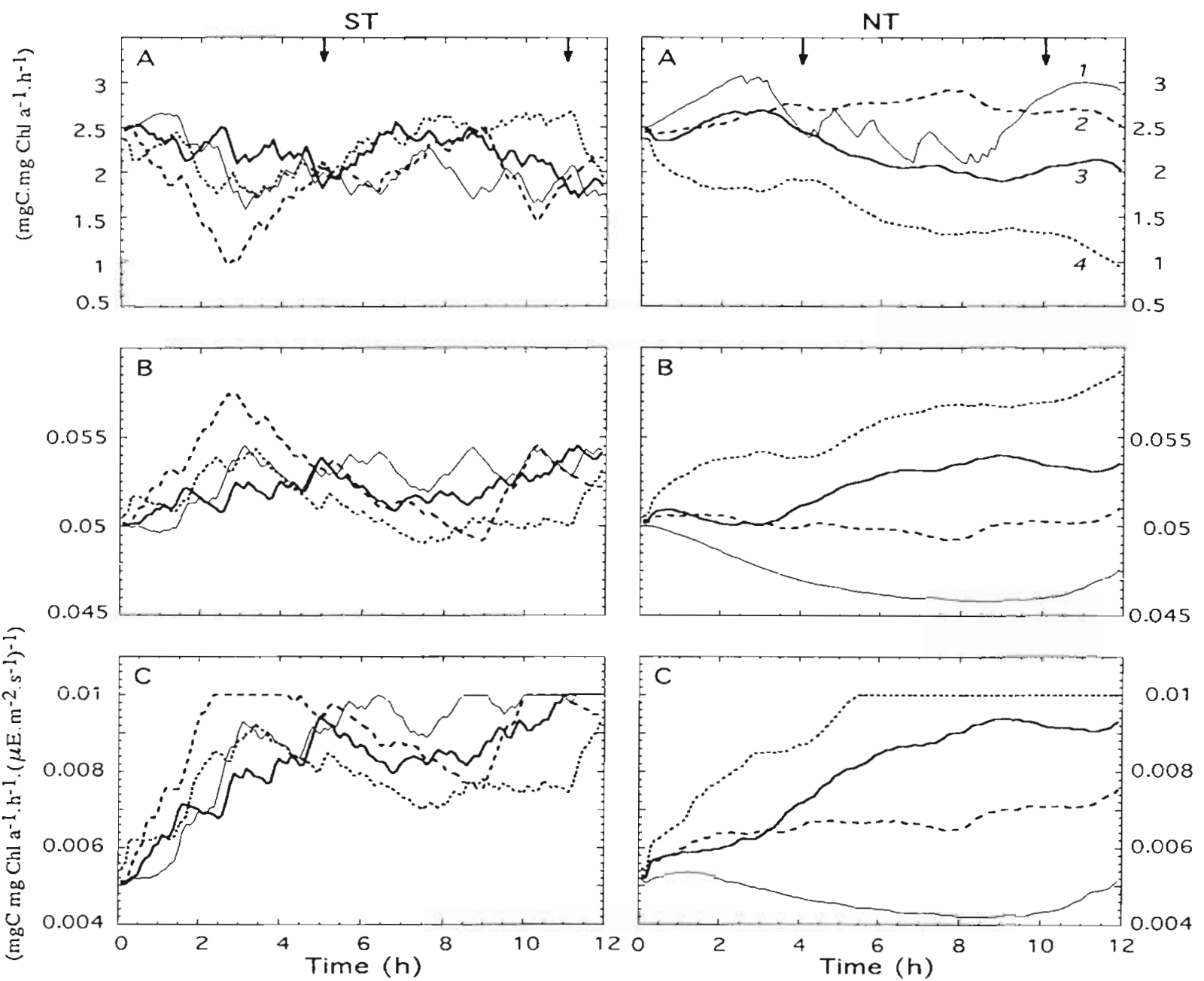

Fig. 3. Variations of the photosynthetic parameters (A) $P_{\mathrm{m}}^{\mathrm{B}},(\mathrm{B}) \alpha^{\mathrm{B}}$ and $(\mathrm{C}) \beta^{\mathrm{B}}$ for 4 individual cells, taken from 4 different depths $(1,5,10$ and $20 \mathrm{~m})$ at spring tide (ST) and at neap tide (NT). Arrows indicate the maximum velocity of the tidal current

characteristics to light variations while they are exported rapidly through the water column. Since the time-scales of vertical mixing become shorter than

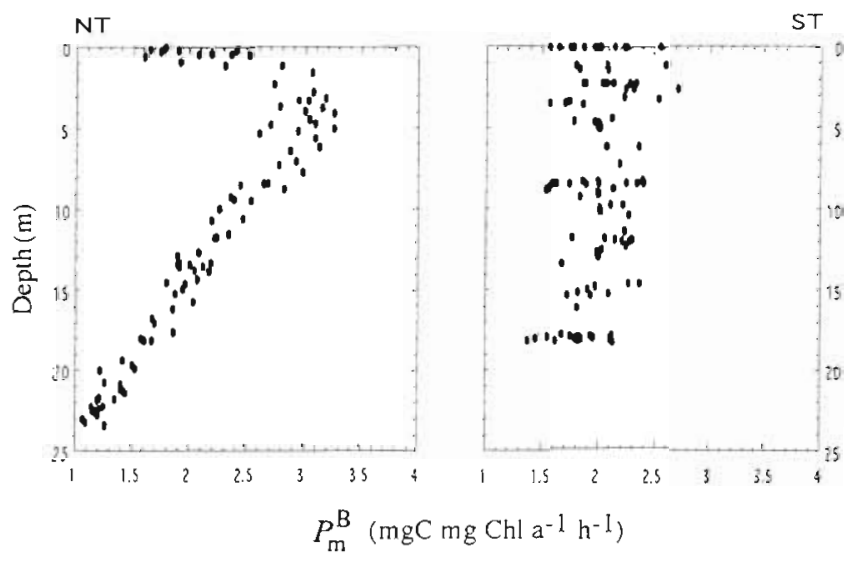

Fig. 4. Vertical gradients of $P_{\mathrm{m}}^{\mathrm{B}}$ at neap tide (NT) and at spring tide (ST) those of the photoadaptation processes at spring tide, cells display only partial adaptations to the light environment. Actually, these photosynthetic parameter heterogeneities at spring tide reflect the large photosynthetic characteristic variability among phytoplankton cells located at the same depth (Fig. 4). Considering that eddy diffusivity is not homogeneously distributed in a water column (Koseff et al. 1993), each cell has its individual light exposure history, and therefore, different cells cannot show similar physiological properties at the same depth, or at different depths at spring tide. In brief, the difference between our results at spring tide and the photoadaptation theory (Falkowski \& Owens 1980) can be explained by the fact that we consider here the individual cell properties and not the population properties, properties on which the photoadaptation theory is based.

Second, vertical gradients of photosynthetic parameters are higher at neap tide than at spring tide (Figs. 3 $\& 5)$ : the vertical variation coefficients (CV) of the pho- 

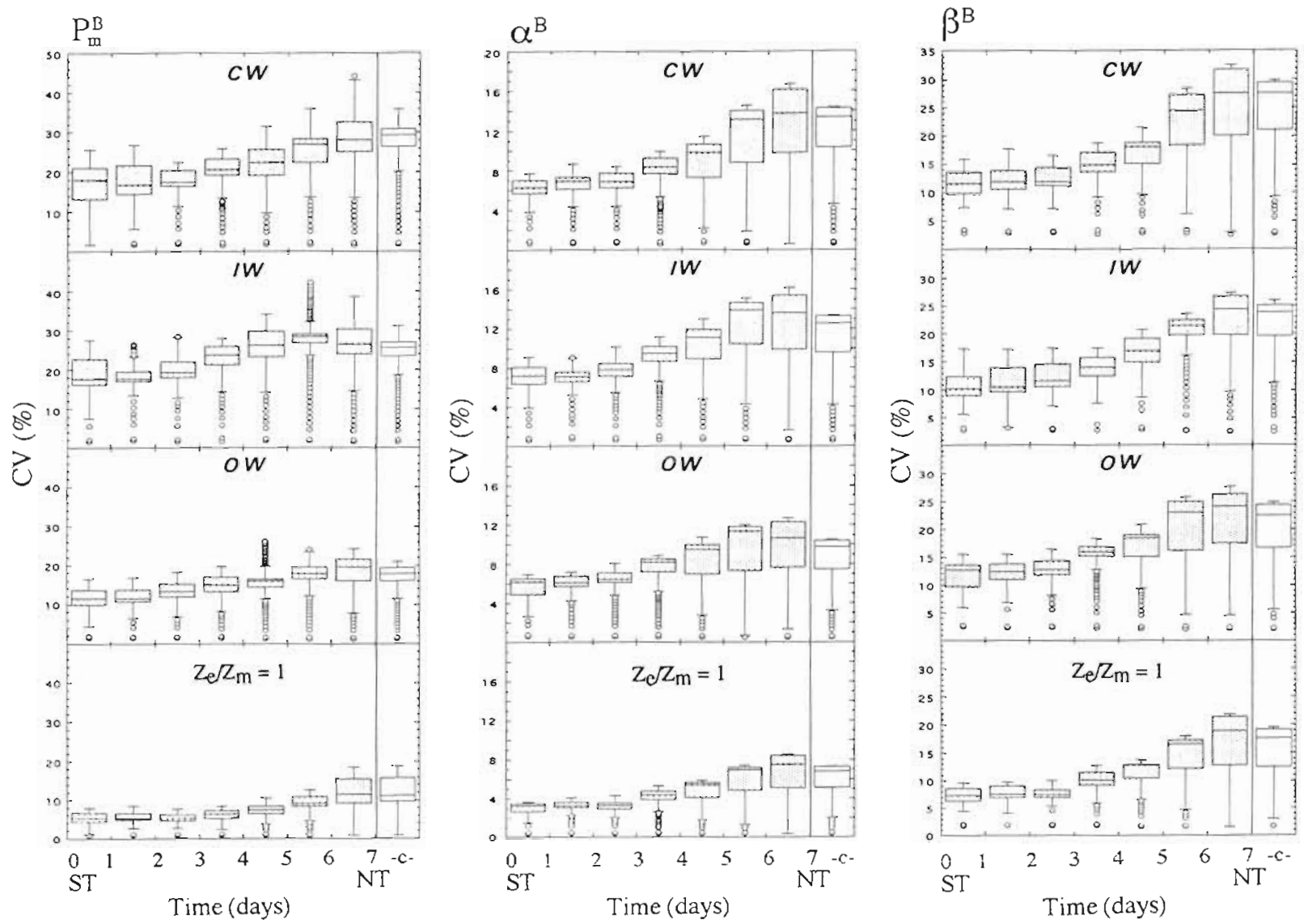

Fig. 5. Box plots showing the increase of the vertical variation coefficients $(\mathrm{CV})$ of the 3 studied photosynthetic parameters $\left(P_{\mathrm{m}}^{\mathrm{B}}\right.$, $\alpha^{\mathrm{B}}$ and $\left.\beta^{\mathrm{B}}\right)$ between spring (ST) and neap tide $(\mathrm{NT})$ conditions, for coastal $(\mathrm{CW})$, intermediate $(\mathrm{IW})$, offshore $(\mathrm{OW})$ and $Z_{\mathrm{a}} / Z_{\mathrm{m}}=1$ water columns. In case c $\left(-c_{-}\right), C l$ of photosynthetic parameters resulting from simulations with a small $K_{\mathrm{v}}$ value of $10^{-5} \mathrm{~m}^{2} \mathrm{~s}^{-1}$ are reported. Box plots show the median (horizontal line in the boxes), quartiles (boxes), and upper/lower 5 th percentiles of all data

tosynthetic parameters display significant increases between spring and neap tide conditions in the 4 studled water columns (Fig, 5, Table 3). These results match with the simulations of Kamykowski et al. (1994) and the field studies of Lewis et al. (1984b). These authors showed, for the first time and from in situ col-

Table 3. Kendall's coefficients of rank correlation ( $\tau$ ) calculated for the box plot medians (cf. Fig. 5) of the vertical variation coefficients $(\mathrm{CV})$ of $P_{\mathrm{m}, \mathrm{B}}^{\mathrm{B}} \alpha^{\mathrm{B}}$ and $\beta^{\mathrm{B}}$, and for the daily primary production rates $(P)$ corresponding to coastal (CW), intermediate (IW), offshore (OW) and $Z_{\mathrm{e}} / Z_{\mathrm{m}}=1$ water columns, between spring and neap tide conditions $(\cdots p<1 \%$, - $p<5 \%$ ). $\tau$ coefficients were calculated between the original data series and the datia series and classified by increasing order (Legendre \& Legendre 1984)

\begin{tabular}{|c|c|c|c|c|}
\hline & $C V P_{\mathrm{I}}^{\mathrm{B}}$ & $\mathrm{CV} \alpha^{\mathrm{B}}$ & $C V \beta^{B}$ & $P$ \\
\hline $\mathrm{CW}$ & $0.810^{\circ}$ & $0.905^{\prime}$ & $0.985 \cdots$ & $0.970 \cdots$ \\
\hline IW & $0.820^{\cdots}$ & $0.865^{*}$ & $0.901^{\cdots}$ & $0.852^{\cdots}$ \\
\hline OW & $0.815^{\cdots}$ & $0.880^{\cdots}$ & $0.850^{\cdots}$ & 0.335 \\
\hline$Z_{\mathrm{e}} / Z_{\ldots}=1$ & $0.765^{\circ}$ & $0.810^{\prime}$ & $0.816^{\cdots}$ & 0.231 \\
\hline
\end{tabular}

lected data, the relationship between vertical heterogeneities of the phytoplankton photosynthetic parameters and the hydrodynamical regimes related to wind forcing. However, it appears from our simulation results that vertical heterogeneities of photosynthetic characteristics are continuous during the day at neap tide, whereas they tend to be reduced, especially for $P_{\mathrm{m}}^{\mathrm{B}}$ when the current speeds are maximum at spring tide (Fig 3). Therefore, the interactions between photoadaptation and vertical mixing at the scale of highlow tidal cycles can occur at spring tide in our model, in the same way as they occur in the eastern English Channel (Lizon et al. 1997).

It must be added that our simulation results show that the $C V$ of $P_{\mathrm{m}}^{B}, \alpha^{B}$ and $\beta^{B}$ are higher in coastal than in $Z_{\mathrm{e}} / Z_{\mathrm{m}}=1$ water columns, at neap tide as well as at spring tide (Fig 5). The weak values of the $\mathrm{CV}$ for $Z_{\mathrm{c}} / Z_{\mathrm{m}}=1$ water columns do not fit with the measurements of photosynthetic responses collected in the eastern English Channel waters. As a matter of fact, Lizon et al. (1995) have shown that vertical heterogeneity of photosynthetic parameters could be on the 

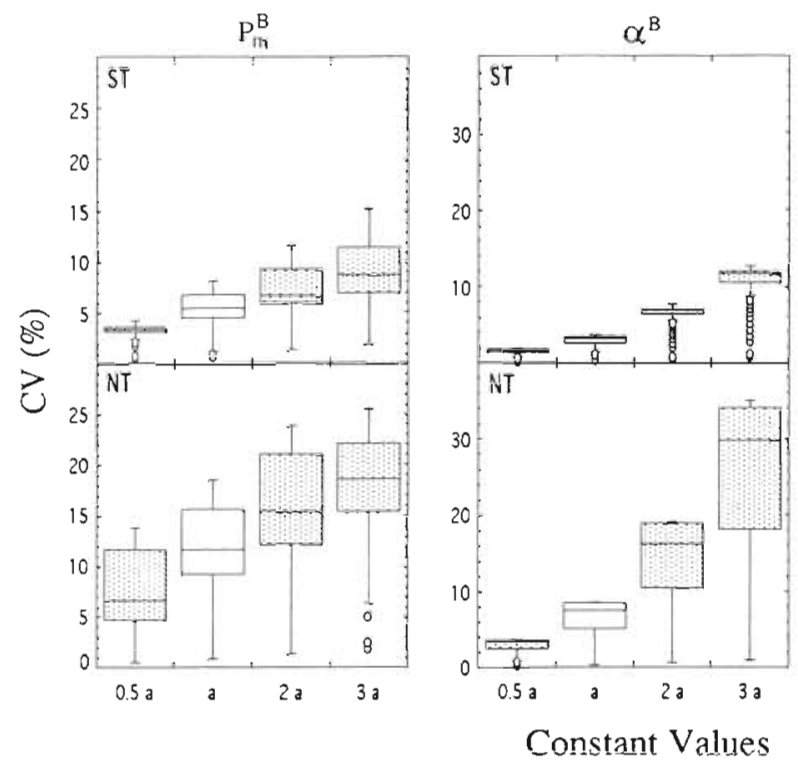

Fig. 6. Box plots showing the vertical variation coefficients $(\mathrm{CV})$ of the 3 studied photosynthetic parameters $\left(P_{\mathrm{m}}^{\mathrm{B}}, \alpha^{\mathrm{B}}\right.$ and $\left.\beta^{\mathrm{B}}\right)$ at spring (ST) and neap tide (NT), for cellspecific constants $a_{\Gamma}$ (cf. Eq. 10 and Table 1) multiplied by the factors $0.5,1,2$ and 3 order of $60 \%$ for water columns where $Z_{e} / Z_{m}=1$. The photoadaptative dynamics used, which is based on our present knowledge of this subject, then is not adequate to generate pronounced vertical gradients of photosynthetic parameters in all water columns. The differences between in situ and modelling observations could be explained by only 1 measurement of the cell-specific constants of the photosynthetic parameters, and under only 1 hydrodynamical condition. Since taxonomic composition of phytoplankton community and cell pigment contents can change, owing to ontogenic adaptations at the scale of the neap-spring tidal cycles (Kirk 1983, Geider et al. 1996), it can be hypothesized that cell-specific constants, which are different with different species (Cullen \& Lewis 1988), could also change at this time-scale and could be specific to water column physical characteristics. Lande \& Lewis (1989) have also suggested that it could be interesting to reconsider the validity of some functions such as Eq. (10), which describe the fully adaptive state of cells $\left(\Gamma_{j}^{*}\right)$. A nonlinear relationship between $\Gamma_{i}^{*}$ and the logarithm of the light intensity incident upon a cell could result in higher heterogeneity in photosynthetic responses between the top and the bottom of a water column. These remarks are supported here by a sensibility analysis of the cell-specific constants $a_{r}$. As a matter of fact, high values of $a_{\Gamma}$ can induce high photosynthetic parameter heterogeneities in a $Z_{\mathrm{e}} / Z_{\mathrm{m}}=1$ water column and higher differences in vertical heterogeneities of the photosynthetic parameters between neap and spring tide conditions (Fig. 6).

Given that variations of vertical tidal mixing intensity could control photoadaptation processes of phytoplankton at the scale of the neap-spring tidal cycles, and also at the scale of high-low tidal cycles at spring tide, the question now is: what is the effect of vertical mixing variations at the neap-spring tidal cycles on the daily primary production rates?

\section{Primary production rates versus vertical mixing}

First of all, the daily primary production rates are noticeably different between the 4 studied water columns, irrespective of the hydrodynamical conditions (Fig. 7A). At spring and neap tides, the higher the ratios between the euphotic zone depths and the mixed layer depths of a given water column, the higher the daily production rates (Fig. 7A). Such results are not surprising, since, when the euphotic zone depth increases, light incident upon the cells located at the bottom of the water column increases and the daily primary production rates of cells also increase. Therefore, the daily primary production rates of cell populations were divided by the average daily light intensities of each mixed layer in order to obtain a standardised index between the different studied water columns (Fig. 7B).

The overall result of our simulations then is an increase in the daily primary production rates between spring and neap tide conditions (Fig. 7B). However, the previous increases in the daily rates are related to the considered water columns, i.e. the values of the $Z_{\mathrm{e}} / Z_{\mathrm{m}}$ ratios. Statistically significant increases, on the order of $40 \%$, are observed in the course of the semi-neapspring tidal cycle, for coastal and intermediate water columns (Table 3). In contrast, for offshore and $Z_{\mathrm{e}} / Z_{\mathrm{m}}=1$ water columns, the tendency toward an increase in daily production rates is not significant from a statistical point of view (Table 3 ). In these last 2 cases, 


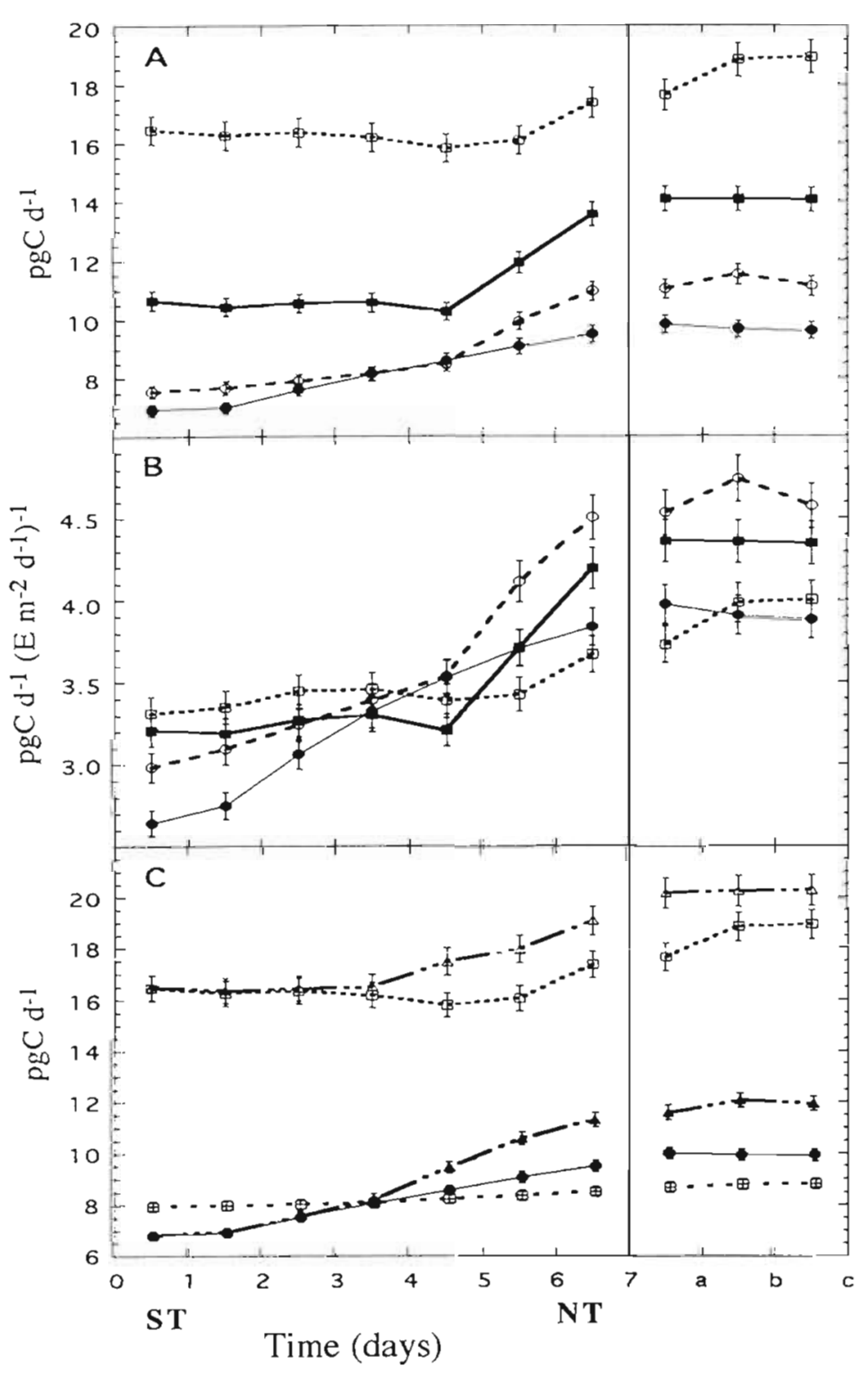

Fig. 7 (A) Daily primary production rates in coastal ( $)$, intermediate (O), offshore ( a) and $Z_{\mathrm{e}} / Z_{\mathrm{m}}=1$ ( $\square$ ) water columns between spring (ST) and neap tide (NT) conditions. (B) Ratios between the daily production rates and the mean daily light intensities of each considered mixed layer. (C) Daily primary production rates considering photoinhibition processes ( and $\square$ ) or not ( $\Delta$ and $\Delta$ ), in coastal ( and $\Delta$ ) and $Z_{\mathrm{e}} / Z_{\mathrm{m}}=1$ ( $\square$ and $\Delta$ ) water columns, and daily primary production rates obtained by excluding photoadaptation processes ( $($ ) ) in our calculations in coastal waters. In the cases $a, b$ and $c$, daily production rates resulting from simulations with small $K_{v}$ values $\left(10^{-3}, 10^{-4}\right.$ and $\left.10^{-5} \mathrm{~m}^{2} \mathrm{~s}^{-1}\right)$ are reported

the increases in daily rates occur late in the course of the semi-neap-spring tidal cycle, and all the more weakly as the $Z_{\mathrm{e}} / Z_{\mathrm{m}}$ ratios are close to unity (Fig. $7 \mathrm{~B}$ ). If a relationship between daily primary production rates and vertical mixing intensities was expected, the influence of the euphotic zone depth on this relationship was not because the vertical heterogeneity of 3 photo- synthetic parameters decreases with an increase in the depth of the euphotic zone (Fig. 5). It can thus be hypothesized that the low $C V$ of photosynthetic parameters in a $Z_{\mathrm{e}} / Z_{\mathrm{m}}=1$ water column would be insignificant compared with the vertical gradients of light considered in the computation of the cell primary production rates. Thus, in a $Z_{\mathrm{e}} / Z_{\mathrm{m}}=1$ water column, low photoadaptation processes would have a weak effect on the daily production rates between spring and neap tide conditions, for which the vertical gradients of light are similar.

Furthermore, the control of daily primary production rates by vertical mixing intensity is made via photoadaptation processes occurring at short time-scales. As a matter of fact, differences in daily primary production rates between spring and neap tide conditions are on the order of $40 \%$ when photoadaptation processes are taken into account in a coastal water column whereas they are on the order of only $4.2 \%$ if photoadaptation processes are not considered (Fig. 7C). Such results concerning the physical control of daily primary production rates vid photoadaptation are in agreement with the simulation results of Barkmann \& Woods (1996), and in disagreement with those of Lande \& Lewis (1989) and Falkowski \& Wirick (1981). As a matter of fact, Barkman \& Woods (1996) also found higher production rates under stable conditions than in turbulent regimes, and differences on the order of $40 \%$ between daily production rates computed for the 2 above-mentioned hydrodynamical conditions. However, our results specify that production rate control can be exerted by vertical mixing generated by the tide (from the bottom of a shallow water column) and occurring periodically at short timescales. In the Barkmann \& Woods (1996) study, vertical mixing of deep water columns was induced by heat flux and wind stress, i.e. by physical processes occurring at longer time-scales than those of vertical tidal mixing, or those of photoadaptation processes. In contrast to our results, Lande \& Lewis (1989) predicted weak production rate differences between low and high turbulent regimes, and Falkowski \& Wirick (1981) concluded that turbulence has very little effect on phytoplankton primary productivity. The discrepancy between these studies and our simulations can be explained by the mixing time-scales considered. For example, Falkowski \& Wirick (1981) used $K_{v}$ values inducing turnover times of a $20 \mathrm{~m}$ depth water 
column, ranging between 110 and $11000 \mathrm{~h}$ for high and low turbulent regimes, respectively. In such conditions, vertical eddy length scales can never be higher than $5 \mathrm{~m}$, and differences in daily production rates between stable and turbulent environments cannot be displayed. Such explanations are supported here by daily primary production rates computed for weak eddy diffusivity values $\left(10^{-3}, 10^{-4}\right.$ and $10^{-5} \mathrm{~m}^{2} \mathrm{~s}^{-1}$ ) (Fig $7 \mathrm{~A}, \mathrm{~B})$ : daily production rates were not different between turbulent conditions resulting from these small $K_{v}$ values and neap tide conditions

From our simulation results, it appears that moderate vertical mixing, such as that encountered here some time before neap tide ( 1 or 2 d before), would not induce an increase in the daily primary production rates, irrespective of the water columns considered There is no decrease in the daily production rates between the fifth and the seventh day of the semineap-spring cycle. Such results refute the hypothesis formulated by Gallegos \& Platt (1985) and Mallin \& Paerl (1992). These authors assert that moderate vertical mixing could stimulate phytoplankton production by tempering light limitation of cells located below the $10 \%$ incident irradiance or by reducing the photoinhibition effect in surface waters. Vertical mixing, however, would control photoinhibition processes, but at the scale of the semi-neap-spring tidal cycle according to the present study. As a matter of fact, Fig. $7 \mathrm{C}$ shows that for 2 different water columns, daily production rates, whether considering photoinhibition or not, are similar at spring tide whereas daily rates differ by about $10 \%$ at neap tide, irrespective of the $Z_{e} / Z_{m}$ ratio values. These results then show, in contrast to the conclusions of Falkowski \& Wirick (1981), that daily primary production rates can be a function of vertical mixing intensity, even if photoinhibition processes are not considered

\section{CONCLUSION}

With reference to our hypothesis, we can conclude that vertical tidal mixing could control daily primary production rates at the scale of the neap-spring tidal cycles in shallow coastal water columns. As a matter of fact, from a simple Lagrangian model, it appears that the decreasing intensity of vertical mixing between spring and neap tide conditions is responsible for a significant increase in daily primary production rates (on the order of $40 \%$ ), via photoadaptation processes occurring at short time-scales, with or without photoinhibition processes. If conclusions of field studies are often inconsistent with respect to the effect of turbulence on primary production rates (increase or decrease) (Marra 1978b, Mallin \& Paerl 1992, Delgadillo-
Hinojosa et al. 1997), this may be due to the competitive effect of light and nutrients in the context of vertical mixing and stratified waters. In the natural environment, vertical mixing can occur at different time-scales, and generate limitations in light, in nutrients, or in both light and nutrients (Huisman \& Weissing 1995, Delgadillo-Hinojosa et al. 1997).

Therefore, primary production in coastal seas - such as the eastern English Channel - would not be only a function of light intensity and nutrient concentrations (Agoumi 1985, Moloney et al. 1986, Hoch 1995, Hoch \& Ménesguen 1995, Ménesguen \& Hoch 1995), but also of photoadaptation processes in relation with vertical tidal mixing intensity. Such processes should be considered in future work on primary production modelling at mesoscales, even if there is some difficulty in identifying this relationship at such scales and in coastal seas (Vézina et al. 1995). As a matter of fact, biological and physical fluctuations in coastal systems can occur faster than the biweekly neap-spring tidal cycles, owing to horizontal advection processes of different water masses (Lizon et al. 1995, Vézina et al. 1995, Brylinski et al. 1996), and can partially hide the relationship between primary production and vertical mixing. However, before conducting further modelling, new experiments must be carried out in order to study the cell-specific constants of photoadaptation processes, for water columns of different $Z_{\mathrm{e}} / Z_{\mathrm{m}}$ ratios, and at the scale of the neap-spring tidal cycles.

Acknowledgements. The authors thank G. Chapalain, J. Steele and S. Monismith for their advice, and J. L. Sardin for a revision of the English of this manuscript. The authors are grateful to $N$. Esquerre and V. Gentilhomme for their assistance during the reciprocal light shift experiments with phytoplankton cells.

\section{LITERATURE CITED}

Agoumi A (1985) Modélisation de l'écosystème pélagique en Manche. Etude de l'influence des phénomènes physiques sur le système planctonique. PhD thesis, University of Paris 6

Baretta JW, Admiraal W, Colijn F, Malschaert JFP, Ruardij P (1995) Tidal flat estuaries. Simulation and analysis of the Ems estuary. Ecol Stud 71:77-104

Barkmann W. Woods JD (1996) On using a Lagrangian model to calibrate primary production determined from in vitro incubation measurements. J Plankton Res 17:767-787

Brylinski JM, Brunet C, Bentley D, Thoumlin G, Hilde D (1996) Hydrography and phytoplankton biomass in the eastern English Chamnel in spring 1992. Estuar Coast Shelf Sci 43:507-519

Capblancq J (1995) Production primaire autotrophe. In: Pourriot $R$, Meybeck $M$ (eds) Limnologie générale. Masson. Paris, p 228-252

Chisholm SW, Armbrust EV, Olson RJ (1986) The individual cell in phytoplankton ecology: cell cycles and application of flow cytometry. Can Bull Fish Aquat Sci 214:343-369 
Cloern JE (1991) Tidal stirring and phytoplankton bloom dynamics in an estuary. J Mar Res 49:203-221

Costanza R (1987) Simulation modeling on Macintosh using STELLA. BioSci 37:129-132

Cullen JJ, Lewis MR (1988) The kinetics of algal photoadaptation in the context of vertical mixing. J Plankton Res 10: $1039-1063$

Delgadillo-Hinojosa F, Gaxiola-Castro G, Segovia-Zavala JA, Munoz-Barbosa A, Orozco-Bordon MV (1997) The effect of vertical mixing on primary production in a bay of the Gulf of California. Estuar Coast Shelf Sci 45:135-148

Demers S, Legendre L (1981) Mélange vertical et capacité photosynthétique du phytoplancton estuarien (estuaire du Saint-Laurent). Mar Biol 64:243-250

Denman KL, Gargett AE (1983) Time and space scales of vertical mixing and advection of phytoplankton in the upper ocean. Limnol Oceanogr 28:801-815

Dyer KR (1986) Coastal and estuarine sediment dynamics. John Wiley \& Sons, New York

Falkowski PG (1983) Light-shade adaptation and vertical mixing of marine phytoplankton: a comparative field study. J Mar Res 41:215-237

Falkowski PG (1980) Light-shade adaptation in marine phytoplankton. In: Falkowski PG (ed) Primary production in the sea. Plenum Press, New York, p 99-119

Falkowski PG, Owens TG (1980) Light-shade adaptation: two strategies in marine phytoplankton. Plant Physiol 66: 592-595

Falkowski PG, Wirick CD (1981) A simulation model of the effects of vertical mixing on primary productivity. Mar Biol 65:69-75

Ferris JM, Christian R (1991) Aquatic primary production in relation to microalgal responses to changing light: a review. Aquat Sci 53:187-217

Fisher HB, List EJ, Koh RCY, Imberger J, Brooks NH (1979) Mixing in inland and coastal waters. Academic Press, New York

Fortier L, Legendre L (1979) Le contrôle de la variabilité à court terme du phytoplancton estuarien: stabilité verticale et profondeur critique. J Fish Res Bd Can 36:1325-1335

Gallegos CL, Platt T (1985) Vertical advection of phytoplankton and productivity estimates: a dimensional analysis. Mar Ecol Prog Ser 26:125-134

Gargett AE, Sanford TB, Osborn TR (1979) Surface mixing layer in the Sargasso Sea. J Phys Oceanogr 9:1090-1111

Geider RJ, Macintyre HL, Kana TM (1996) A dynamic model of photoadaptation in phytoplankton. Limnol Oceanogr 41:1-15

Grobbelaar JU (1994) Turbulence in mass algal cultures and the role of light/dark fluctuations. J Appl Phycol 6: $331-335$

Hannon B, Ruth M (1994) Dynamic modeling. Springer-Verlag, New York

Harris GP (1980) The relationship between chlorophyll a fluorescence, diffuse attenation changes and photosynthesis in natural phytoplankton populations. J Plankton Res 2: 109-127

Hoch T (1995) Modélisation du cycle biogéochimique des éléments limitant la production biologique en Manche $(N, P$. Si]. PhD thesis, University of Paris 7

Hoch T, Ménesguen A (1995) Modelling the biogeochemical cycles of elements limiting primary production in the English Channel. II. Sensitivity analyses. Mar Ecol Prog Ser 146:189-205

Huisman J, Weissing FJ (1995) Competition for nutrients and light in a mixed water column: a theoretical analysis. Am Nat 146(4):536-564
Janowitz CS, Kamykowski D (1991) An Eulerian model of phytoplankton photosynthetic response in the upper mixed layer. J Plankton Res 13:983-1002

Kamykowski F, Yamazaki H, Janowitz GS (1994) A Lagrangian model of phytoplankton photosynthetic response in the upper mixed layer. J Plankton Res 16:1059-1069

Kirk JTO (1983) Light and photosynthesis in aquatic ecosystems. Cambridge University Press, Cambridge

Koseff JR, Holen JK, Monismith SG, Cloern JE (1993) Coupled effects of vertucal mixing and benthic grazing on phytoplankton populations in shallow, turbid estuaries. J Mar Res 51:843-868

Kromkamp J, Limbeek M (1993) Effect of short-term variation in irradiance on light harvesting and photosynthesis of the marine diatom Skeletonema costatum: a laboratory study simulating vertical mixing. J Gen Microbiol 139: $2277-2284$

Lande R, Lewis MR (1989) Models of photoadaptation and photosynthesis by algal cells in a turbulent mixed layer. Deep Sea Res 36:1161-1175

Legendre L, Legendre P (1984) Ecologie numérique 2: la structure des données écologiques. Masson, Paris

Lewis MR, Cullen JJ, Platt T (1984a) Relationships between vertical mixing and photoadaptation of phytoplankton: similarity criteria. Mar Ecol Prog Ser 15:141-149

Lewis MR, Horne EPW, Cullen JJ, Oakley NS, Platt T (1984b) Turbulent motions may control phytoplankton photosynthesis in the upper ocean. Nature 311:49-50

Li WKW, Woods AM (1988) Vertical distribution of North Atlantic ultraphytoplankton: analysis by flow cytometry and epifluorescence microscopy. Deep Sea Res 35: $1615-1638$

Lizon F (1997) Photoadaptation et évaluation de la production photosynthétique du phytoplankton en relation avec les caractéristiques hydrodynamiques de la Manche Orientale. PhD thesis. University of Paris 6

Lizon F, Lagadeuc Y (1998) Comparisons of primary production values estimated from different incubation times in a coastal sea. J Plankton Res 20:371-381

Lizon F, Lagadeuc Y, Brunet C, Aelbrecht D, Bentley D (1995) Primary production and photoadaptation of phytoplankton in relation with tidal mixing in coastal waters. J Plankton Res 17:1039-1055

Mallin MA, Paerl HW (1992) Effects of variable irradiance on phytoplankton productivity in shallow estuaries. Limnol Oceanogr 37:54-62

Marra J (1978a) Phytoplankton photosynthetic response to vertical movement in a mixed layer Mar Biol 46:203-208

Marra J (1978b) Effect of short-term variations in light intensity on photosynthesis of a marine phytoplankter- a laboratory simulation study. Mar Biol 46:191-202

Marra J (1980) Vertical mixing and primary production. In: Falkowski PG (ed) Primary production in the sea. Plenum Press, New York, p 78-85

McGillicuddy DJ, Robinson AR, McCarthy JJ (1995) Coupled physical and biological modelling of the spring bloom in the North Atlantic (II): three dimensional bloom and postbloom processes. Deep Sea Res 42:1359-1398

Ménesguen A, Hoch T (1995) Modelling the biogeochemical cycles of elements limiting primary production in the English Channel. I. Role of thermocline stratification. Már Ecol Prog Ser 146:173-188

Moloney CL, Bergh MO, Field JG, Newell RC (1986) The effect of sedimentation and microbial nitrogen regeneration in a plankton community: a simulation investigation. J Plankton Res 8:427-445

Montagnes DJS, Berges JA (1994) Estimating carbon, nitro- 
gen, protein, and chlorophyll a from volume in marine phytoplankton. Limnol Oceanogr 39:1044-1060

Neale PJ, Richardson PJ (1.987) Photoinhibition and the diurnal variation of phytoplankton photosynthesis. I. Development of a photosynthesis-irradiance model from studies of in situ responses. J Plankton Res 9:167-193

Olson RJ, Zettler ER, Chisholm SW, Dusenberry JA (1991) Advences in oceanography through flow cytometry. In: Demers $S$ (ed) Particule analysis in oceanography. Springer-Verlag, Berlin, p 351-402

Perry MJ, Talbot MC, Alberte RS (1981) Photoadaptation in marine phytoplankton: response of the photosynthetic unit. Mar Biol 62:91-101

Pielou EC (1969) An introduction to mathematical ecology. Wiley Interscience, New York

Platt T, Gallegos CL, Harrison WG (1980) Photoinhibition of photosynthesis in natural assemblages of marine phytoplankton. J Mar Res 38:687-701

Richmond B, Peterson S, Vescuso P (1987) An academic user's guide to STELLA. High Performance System, Lyme, NH

Seuront L, Schmitt F, Lagadeuc Y, Schertzer D, Lovejoy S, Frontier S (1906a) Multifractal analysis of phytoplankton biomass and temperature in the ocean. Geophys Res Lett 23:3591-3594

Seuront L, Schmitt F, Schertzer D, Lagadeuc Y, Lovejoy S (1996b) Multifractal intermittency of Eulerian and Lagrangian turbulence of orean temperature and plankton fields. Nonlin Proc Geophys 3:236-246

Shay TJ, Gregg MC (1986) Turbulence in an oceanic convective mixed layer. Nature 310:282-285

Simpson JH, Brown J, Matthews J, Allen G (1990) Tidal

Editorial responsibility: Otto Kinne (Editor),

Oldendorf/Luhe, Germany straining, density currents, and stirring in the control of estuarine stratification. Estuaries 13:125-132

Simpson JH, Sharples J, Rippeth TP (1991) A prescriptive model of stratification induced by freshwater runoff. Estuar Coast Shelf Sci 33:23-35

Skogen MD, Svendsen E, Berntsen J, Aksnes D, Ulvestad KB (1995) Modelling the primary production in the North Sea using a coupled three-dimensional physical-chemical-biological ocean model. Estuar Coast Shelf Sci 41:545-565

Taylor GI (1954) The dispersion of matter in turbulent flow through a pipe. Proc R Soc Lond 223:446-448

Vézina AF, Gratton Y, Vinet P (1995) Mesoscale physical-biological variability during a summer phytoplancton bloom in the Lower St Lawrence estuary. Estuar Coast Shelf Sci 41:393-411

Vincent WF, Neale PJ, Richardson PJ (1984) Photoinhibition: alga responses to bright light during diel stratification and mixing in a tropical lake. J Phycol 20:201-211

Weissing FJ, Huisman J (1994) Growth and competition in a light gradient. J Theor Biol 168:323-336

Woods JD, Barkmann W (1994) Simulating plankton ecosystems by the Lagrangian Ensemble method. Phil Trans R Soc Lond B 343:27-31

Woods JD, Onken R (1982) Diurnal variation and primary production in the ocean-preliminary results of a Lagrangian Ensemble model. J Plankton Res 4:735-756

Wu J, Vankat JL (1991) An area-based model of species richness dynamics of forest islands. Ecol Model 58:249-27

Yamazaki H, Kamykowski D (1991) The vertical trajectories of motile phytoplankton in a wind-mixed water column. Deep Sea Res 38:219-241

Submitted: December 22, 1997; Accepted: May 26, 1998

Proofs received from author(s): July 13, 1998 